See discussions, stats, and author profiles for this publication at: https://www.researchgate.net/publication/280972522

\title{
Unpacking the effect of exploration during environmental uncertainty: Evidence from the information technology sector
}

Article in Canadian Journal of Administrative Sciences / Revue Canadienne des Sciences de I Administration · June 2015 Dol: $10.1002 /$ cjas.1330

\section{CITATIONS}

4 authors, including:

2. Samir Shrivastava

Swinburne University of Technology

14 PUBLICATIONS 274 CITATIONS

SEE PROFILE

Peter McNamara

National University of Ireland, Maynooth

48 PUBLICATIONS 330 CITATIONS

SEE PROFILE

Some of the authors of this publication are also working on these related projects:

Business Models and Firm Performance View project

Project Knowledge Management View project

\section{READS}

35

Federica Pazzaglia

University College Dublin

25 PUBLICATIONS 266 CITATIONS

SEE PROFILE 


\section{Unpacking the effect of exploration during environmental uncertainty: Evidence from the information technology sector}

\author{
Samir Shrivastava* \\ Swinburne University of \\ Technology
}

\author{
Federica Pazzaglia \\ University College Dublin
}

\author{
Karan Sonpar \\ University College Dublin
}

\author{
Peter McNamara \\ Maynooth University, National \\ University of Ireland
}

\begin{abstract}
Environmental uncertainty can render managerial decisionmaking about resource deployment particularly difficult. Integrating the knowledge-based view of the firm and the organizational learning literature, we make a case for deploying specific knowledge-based resources to cope with specific types of environmental uncertainty. We unbundle knowledge-based resources into technology-based and social-network-based resources and, using Milliken's (1987) typology of environmental uncertainty, we hypothesize that (a) technological exploration will be more effective during state uncertainty and (b) while being generally beneficial, social exploration will prove more effective during response uncertainty. An analysis of the financial performance of information technology (IT) firms in the United States over the period 1995-2004 generally supports our hypotheses. Copyright (C) 2015 ASAC. Published by John Wiley \& Sons, Ltd.
\end{abstract}

Keywords: environmental uncertainty, exploration, organizational learning, knowledge-based view

\section{Résumé}

L'incertitude environnementale peut rendre la prise de décision managériale concernant le déploiement des ressources particulièrement difficile. Combinant la perspective de l'entreprise basée sur le savoir et les travaux en apprentissage organisationnel, cet article est en faveur du déploiement des ressources spécifiques basées sur le savoir pour faire face à des types spécifiques d'incertitude environnementale. Nous divisons les ressources basées sur le savoir en ressources basées sur la technologie et en ressources basées sur le réseau social et, nous appuyant sur la typologie de Milliken (1987) sur l'incertitude environnementale, nous posons comme hypothèse que (a) l'exploration technologique est plus efficace pendant l'incertitude étatique, et (b) quoique généralement avantageuse, l'exploration sociale est plus efficace pendant l'incertitude de la réponse. Une analyse de la performance financière des firmes de la technologie de l'information (IT) aux États-Unis de 1995 à 2004 montre que l'exploration technologique menée à travers l'investissement en $R$ et $D$ est positivement reliée à la performance financière de la firme en période d'incertitude étatique, mais non pas en période d'incertitude de la réponse. Par ailleurs, l'impact de l'exploration sociale sur la performance financière de la firme en période d'incertitude de la réponse produit des résultats plutôt mitigés. Copyright (C) 2015 ASAC. Published by John Wiley \& Sons, Ltd.

Mots-clés : incertitude environnementale, exploration, apprentissage organisationnel, perspective basée sur le savoir, point chaud
Globalization, rapid technological advances, intense competitive rivalry, and ever-changing regulatory regimes can all combine to make business environments highly

*Please address correspondence to: Samir Shrivastava, Faculty of Business and Law, Swinburne University of Technology, Australia. Email: s.shrivastava@swin.edu.au uncertain. Firms attempt to cope by creating, extending, and modifying or reconfiguring their resource base (Helfat et al., 2007) depending on how they perceive environmental uncertainty. In other words, environmental uncertainty can influence the way firms deploy their resources. The resource deployment decisions made by firms are perhaps best captured by March's (1991) succinct taxonomy, which describes such decisions as being either exploration- or 
exploitation-oriented. Exploration entails allocating resources in "pursuit of new knowledge," whereas exploitation involves the "use and development of things already known." (Levinthal \& March, 1993, p. 105). The literature, however, asserts that firms need to be ambidextrous - that is, firms must be adept at both exploring and exploiting knowledge-based resources (Tushman \& O'Reilly, 1996), and vary the amount of emphasis they place on either exploration or exploitation depending on the context (Lavie, Stettner, \& Tushman, 2010). The important question therefore is: Under what context or contingency do firms benefit from deploying resources primarily for exploration, and when do they benefit from exploiting their knowledge-based resources? Since the extant literature does not adequately address this question (Lavie et al., 2010; O'Reilly \& Tushman, 2013), we attempt to provide a partial answer.

Our answer is partial in the sense that we focus only on exploration. We do so for two reasons. Firstly, exploration, by definition, is critical to the ability of firms to innovate, and it is widely acknowledged that firms must continually innovate if they are to sustain their competitive advantage (Sosa, 2013). Secondly, exploratory activities have proven more effective during periods of uncertainty than during periods of stability (Jansen, Van Den Bosch, \& Volberda, 2006; Matusik \& Fitza, 2012; Sidhu, Volberda, \& Commandeur, 2004). In current times, firms operate in an increasingly uncertain environment and must necessarily focus on exploration. Although scholars have studied the link between environmental uncertainty and resource deployment, they have generally made coarse-grained distinctions among time periods. For example, they have differentiated between "stable and unstable" periods and overlooked the fact that there are different types of uncertainty (exceptions include Ashill \& Jobber, 2010; Beckman, Haunschild, \& Phillips, 2004; McKelvie, Haynie, \& Gustavsson, 2011; Miller \& Shamsie, 1999). As explained below, there may be merit in focusing on different types of uncertainty in the resource allocation context.

Milliken (1987) conceptualized uncertainty as a multifaceted construct and identified three distinct types of uncertainty: (i) state uncertainty, which makes it difficult to discern what is going on and therefore renders predictions about the future state of the world suspect; (ii) effect uncertainty, which makes it difficult to predict the impact of the environmental changes on one's organization; and (iii) response uncertainty, which makes it difficult to predict the organizational consequences of a particular response/action. Although enhancing organizational performance remains the central concern of strategy (see Crossan \& Apaydin, 2010; Urgal, Quintas, \& Arevalo-Tome, 2013), empirical studies that explain how environmental aspects impact exploratory and exploitative strategies on organizational performance are scarce (Jansen et al., 2006; Lavie et al., 2010). In this paper, we attempt to advance the current understandings of the impact of resource deployment decisions by linking Milliken's (1987) concepts of state and response uncertainty to specific exploratory strategies and by studying their effects on organizational performance.

While we note that dynamic environments render existing products and services obsolete (Jansen et al., 2006) and that firms in general are said to benefit from relying on exploration during uncertainty (Miller \& Shamsie, 1996; Sidhu et al., 2004), we concur with the view that "exploration" as defined in the extant literature is much too broad and does not lend itself to being operationalized and measured with precision (Lavie et al., 2010). We argue that, just as there are different types of uncertainty, there are different types of exploration. Differentiating amongst exploratory activities could facilitate our understanding of how exploration adds value to the firm. We turn to Milliken's (1987) framework to provide a sound theoretical rationale for establishing linkages between types of uncertainty, specific exploratory strategies, and firm-level performance outcomes. We unbundle exploratory knowledge-based resources into (a) technology-based resources (i.e., technological exploration as typified by research and development or R\&D activity), and (b) social-network based resources (i.e., social exploration as typified by organizational attempts to leverage managerial and interfirm networks into commercialization opportunities). We later contend that there are theoretical reasons to favour technological exploration during state uncertainty and social exploration during response uncertainty. We also provide some empirical evidence to support our arguments by linking the two kinds of exploration to the performance of information technology (IT) firms located in geographical hot spots and those located outside hot spots in the US. Our data belong to the predotcom (1995-1998) and postdotcom (2001-2004) bubble periods. We argue that the two periods may reasonably be seen as respectively reflecting state and response uncertainty.

We demonstrate a method that obviates the need to rely on subjective judgments to measure different states of uncertainty and resource deployment decisions. Our study advances the organizational learning literature and the knowledge based view (KBV) of the firm by providing evidence that deploying specific knowledge-based resources during specific types of environmental uncertainty (Milliken, 1987) positively impacts firm performance.

\section{Hypotheses Development}

\section{Uncertainty and Knowledge-Based Resources}

The role of uncertainty is fundamental to the field of strategic management since it affects the response of organizations, particularly the strategic decision making of top managers (Mitchell, Shepherd, \& Sharfman, 2011). The more important strategic decisions pertain to attempts by managers to create rents by deploying resources more effectively than the competition (Makadok, 2001). It is 
important to note however that sound resource deployment decisions, while necessary for competitive advantage, are not sufficient. The resource-based view (RBV) of the firm draws attention to the characteristics of the resources possessed by the firms. Competitive advantage derives from uniquely endowed tangible or intangible resources-that is, from resources that are valuable, rare, and hard to imitate or substitute (Barney, 1991). A variant of the RBV is the knowledge-based view (KBV) of the firm (Grant, 1996), which essentially implies that knowledge-based resources confer competitive advantage because they cannot be easily imitated. Knowledge-based resources are said to be comprised of skillsets that enable firms to "adapt their products to market needs and to deal with competitive challenges" (emphasis added; Miller \& Shamsie, 1996, p. 522). Adaption implies the ability to achieve congruence with the changing business environment.

The KBV thus implies that knowledge-based resources can confer competitive advantage only if deployed appropriately (i.e., in congruence with the external environment). The KBV's fundamental premises may be summarized as follows: (a) firms are complex social communities that manage knowledge (Kogut \& Zander, 1992, 1996); (b) knowledge is the key resource that impacts firm performance (Grant, 1996); (c) knowledge can be integrated only by a firm and not an industry (Grant, 1996); (d) benefitting from knowledge requires organizations to engage in both exploratory and exploitative behaviours (DeCarolis \& Deeds, 1999; Lavie et al., 2010; March, 1991); and (e) the limits to managerial attention and organizational capacity to indulge in both exploratory and exploitative behaviour implies that organizations make trade-offs and tend to focus on one or the other (Levinthal \& March, 1993).

As noted, a firm's ability to make sound resource deployment decisions enables it to achieve congruence in an uncertain environment. But evidence suggests that achieving such congruence is not easy. Uncertainty places unreasonable demands on the cognitive processing abilities of managers and makes them prone to erratic decisionmaking (Mitchell et al., 2011) at the very time when there is a greater premium on sound resource deployment decisions. In fact, Miller and Shamsie's (1999) study establishes that state, effect, and response uncertainty impairs resourcedeployment decisions by sending conflicting signals to managers. Their study examined how different types of uncertainties engendered different strategic responses from Hollywood studios with regards to variety in their product offerings between 1936 and 1965.

State uncertainty in Milliken's (1987) formulation pertains to the inability to make sense of the macro-level environmental changes. For example, currently the convergence of smart mobility, cloud computing, social networking, and big data analytics has created a great deal of state uncertainty in the technology sector. $R \& D$ investments may assist in exploring and legitimizing the technologies that enable the potential of technological convergence to solve problems that customers will ultimately pay for. Additionally, the regulatory regimes of different nation-states too will play a role. For instance, national priorities may impact the availability of sufficient bandwidth for the projected number of Wi-Fi applications. The performance attributes of some of these technologies are still developing and one cannot predict how technological advances will effect individual organizations. Thus effect uncertainty is also at play. Unsurprisingly, the sector is witnessing higher than usual merger and acquisition activity (EY News Release, 2012), which indicates that organizations are deploying their resources to prepare for an uncertain future. Eventually, the organizations must respond. For instance, traditional copper wire telecommunication providers now must decide on the segment of the emerging consumer multimedia market they wish to compete in. The decision by the US telecom company AT\&T to leverage cloud computing and invest in video on demand services (AT\&T Newsroom, 2014) is a case in point.

Response uncertainty, as the AT\&T example illustrates, pertains to managers experiencing the pressure to respond without being in a position to confidently predict the outcomes or consequences of their decisions. It is almost impossible for managers to foresee which technology will eventually get profitability embedded in the technological ecosystem. Thus, managerial decisions during such times must necessarily be based on tentative projections. More generally, the degree of confidence in the resource deployment decisions made by decision makers during state uncertainty tends to be inversely proportional to the levels of causal ambiguity experienced by them. Arguably, decision making would improve if managers were to focus only on a limited number of key variables. A sharper focus would produce greater clarity around cause-effect linkages and thereby diminish the levels of causal ambiguity experienced by managers. In the next section, we build on the fact that exploratory, as opposed to exploitative, activities have been found effective during uncertain times. To facilitate greater clarity, we attempt to link specific types of uncertainty with specific exploratory activities.

\section{Specific Types of Exploration for Specific Types of Uncertainty}

Exploration is "the pursuit of new knowledge, of things that might come to be known" (Levinthal \& March, 1993, p. 104). While exploitation pertains to improving present performance through incremental activities such as execution and process-refinement, exploration is more about searching and experimenting new processes so as to effect improvements in future performance (Levinthal \& March, 1993). Lavie and colleagues (2013) have cited ample evidence to support the assertion that exploration proves more effective during uncertain times (e.g., Jansen et al., 2006; Sidhu et al., 2004) than does exploitation (e.g., Gupta, 
Smith, \& Shalley, 2006). We thus accept the fit between exploratory activities and uncertainty as a point of departure and build on our intuition that it may pay dividends to further analyze exploratory activities.

Prior research has found that a wide range of exploratory activities can lead to superior performance. The activities include, but are not limited to: the acquisition of creative talent (e.g., Miller \& Shamsie, 1996); accessing and developing knowledge-based stocks by building ties with partners (e.g., Stuart, 2000); allocating internal resources for search and R\&D (e.g., Li, 2013); and choosing to locate in areas that facilitate access to knowledge and knowledge spillovers (e.g., DeCarolis \& Deeds, 1999). A closer examination of the above mentioned exploratory activities reveal how the activities involve both technological and social elements. Also, technology-related activities tend to have an internal focus in that they concentrate on developing and exploring the potential of a technology, whereas social activities have an external focus and pertain to the process of understanding how to fit into a commercialization ecosystem. This is consistent with the innovation literature that draws attention to "the tension between external and internal sources of innovation" (Crossan \& Apaydin, 2010, p. 1165). We contend below that there are theoretical reasons to undertake technology-based exploratory activities during state uncertainty and social network-based exploratory activities during response uncertainty.

Technological exploration and state uncertainty. We define technological exploration as activities that are focused on the pursuit of innovation through research and development activities. During state uncertainty, all actors immersed in the environment in question (i.e., the entire industrial ecosystem) are equally "ignorant" and can do no more than attempt to generate plausible future scenarios and prepare for them to the extent possible. State uncertainty creates doubt about the future prospects of existing product lines and makes it difficult to predict which technologies will eventually prevail. Under such circumstances, it makes sense for decision makers to hedge their bets and focus on broadening their firm's knowledge base in the hopes of positioning it to seize an opportunity once there is more clarity. Firms inclined to commit strategic resources for a major new initiative during a period of state uncertainty must necessarily take an ill-informed risk. We expect that investors will penalize firms for undertaking such unduly risky initiatives and instead reward those undertaking more conservative ones. They may see technological exploration, especially high investments in $R \& D$, as evidence that the firm is working to cope with technological uncertainty.

The argument that attempts to explore or innovate should be favoured during state uncertainty is somewhat counter-intuitive. As Henderson (1999, p. 290) observed, "Exploration involves inventing new technologies. Its financial returns are potentially large, but they are also risky and tend to occur in the distant future...exploitation involves the refinement of existing technologies. Its financial returns are relatively certain and immediate..." Exploration is also said to enhance an "organization's future adaptability while incurring greater risk and opportunity costs" (Lavie et al., 2010, p. 137). Nonetheless, we argue that state uncertainty prevents an estimate of opportunity costs as one cannot ascertain which opportunities, if any, are foregone by the firms. Thus technological exploration, especially as typified by a focus on $R \& D$ activities, is a prudent option during state uncertainty. In general, strategic management scholars have argued that increases in $\mathrm{R} \& \mathrm{D}$ expenses positively affect firm performance as they facilitate the introduction of valuable innovations that fulfill previously unmet consumer demands. This positive effect is particularly strong in knowledge-intensive industries (DeCarolis \& Deeds, 1999).

A focus on innovation can be expected to pay off during turbulent environments because in the face of hostility, firms become better at executing their innovation strategies. Firms which fail to innovate under such circumstances often find their core competences becoming core rigidities (LeonardBarton, 1992) as Polaroid, the conventional photo technology provider, discovered with the advent of digital image capturing technologies. The Polaroid example indicates that firms must respond as soon as the levels of state uncertainty are lowered. It stands to reason that firms that move aggressively to gain an early mover advantage would be rewarded by the investor community during periods of response uncertainty. Conversely, conservative firms that continue investing heavily in $R \& D$ at the expense of seizing an existing opportunity would be penalized. This is exactly what Jakopin and Klein (2012) found. These authors reported that incumbent copper wire telecommunication players that took the risk and seized the opportunity to operate mobile networks out-performed late entrants into the sector across 149 countries. Extant evidence suggests that technological exploration is particularly valuable in times of state uncertainty when there is a lack of clarity on the extent of environmental munificence, and when the market interprets aggressive pursuit of $R \& D$ as a sign of a promising product line. Thus, we posit:

\section{H1: $R \& D$ intensity will have a positive relationship with financial market performance in times of state uncertainty but not in times of response uncertainty.}

Social exploration and environmental uncertainty. We define social exploration as activities that allow a firm to source knowledge externally, concentrating on the process of understanding how to fit into a commercialization ecosystem, such as through the transfer of personnel or through social networks. Such networks have been closely linked to a firm's ability to innovate (see Gubbins \& Dooley, 2014). We hold that social exploration, whether consciously or otherwise, is greatly facilitated in firms located in hot spots because locating close to others enables sharing of tacit knowledge about the 
commercialization ecosystem. Exploring the ecosystem enables the firm to work out how to move from technological legitimization to being a legitimate element of the technology commercialization ecosystem. Thus, a hot spot location could be taken as a proxy measure for social exploration. Hot spots have been defined as "fast growing, geographically clustered firms within industries" (Pouder \& St. John, 1996, p. 1192). Some examples of hot spots are: Bangalore and Hyderabad in India for call centres; the Third-Italy region (a few towns and cities in the north-east of Italy) for clothing and ceramics; Saskatoon in Canada for its agricultural biotechnology firms; Hollywood for its film-related industrial ecosystem; or Wall Street for its finance industry.

A prominent feature of hot spots is the presence of an extensive network of linkages between firms, which facilitate the transfer of knowledge through frequent and repeated interactions that can in turn become a source of competitive advantage (McCann \& Folta, 2009; Pouder \& St. John, 1996). The benefits of agglomeration of knowledge intensive firms such as dotcoms are primarily supply side (see McCann \& Folta, 2009 for a review) and include: greater access to sources of funds (DeCarolis \& Deeds, 1999); access to a large pool of knowledge-workers; proximity to complementary industries; and access to information on emerging best practices in the industry (Kukalis, 2010). As Marshall (1920) had observed almost a century ago, information is almost in the air in geographic clusters. Even if firms and managers do not consciously attempt to build and leverage their social networks, they perhaps cannot help benefitting from being located in hot spots. While the generic benefits of a hot spot location are well understood and acknowledged, little is known about how, if at all, interaction effects between a hot spot location and types of uncertainty impact firm performance.

In many ways, state uncertainty tends to level the playing field and facilitates the entry of new players into an industry. Incumbent firms, much like new entrants, must deal with response uncertainty by deploying resources to seize an opportunity. Arguing that opportunities in high uncertainty environments can be fleeting and "opportunity only favours the prepared," Li, Chen, Liu, and Peng (2014, p, 272 ) reported that new ventures with stronger interfirm and managerial ties display higher levels of exploratory learning and are more successful at opportunity capture than are new venture firms with low levels of social capital. Another empirical study on product innovation found that the two phases of new product development-the initiation and the implementation phase-respectively called for exploratory and exploitative learning ( $\mathrm{Li}, 2013)$. Overall, the initiation phase may be seen as unfolding during a period of state uncertainty and the implementation phase coinciding with a period of response uncertainty. That firms prepare for the initiation phase through undertaking internal exploratory activities (e.g., R\&D initiatives) is consistent with arguments put forth in support of $H 1$. Interestingly, the efficacy of exploitative learning during the implementation phase does not necessarily undermine the importance of social exploration during response uncertainty.

As $\mathrm{Li}$ (2013) pointed out, it is not as if exploration is not needed during the implementation phase. This author explained that exploitative learning during implementation focuses mainly on competitor and market knowledge with a view to ensuring superior product positioning in the market. We argue that managerial networking in hot spots can help firms gather the much-needed competitive and market intelligence to complement exploitative learning during response uncertainty. Furthermore, we note that well-developed social networks in hotspots provide access to a diverse knowledge base which can, in turn, contribute to superior problem solving. Diverse inputs and ideas have been found to increase the possibility of discovering novel linkages and enhance the quality of strategic decision making (Matusik \& Fitza, 2012). Similarly, Combs, Ketchen, Ireland, and Webb (2011) also implied that incumbent firms can cope with response uncertainty by combining or bundling their existing resources in new ways, or leveraging their resources in entirely new domains. Again, we argue that social exploration would facilitate the kind of thinking needed to respond in novel ways.

Our intuition that social exploration could help firms cope with response uncertainty is supported by another study that describes uncertainty as being either "collective" or "firm-specific" (see Beckman et al., 2004). We argue that major macro-economic changes and technological advances as witnessed during state uncertainty can unsettle all firms within a sector, irrespective of their geographical location. Therefore, firms may be said to experience collective uncertainty during state uncertainty. Having invested in their chosen technologies and configured their resources uniquely, firms eventually must respond by launching a particular product or service as state uncertainty subsides. Therefore, during response uncertainty, firms may be described as facing firm-specific uncertainty. Beckman and colleagues report that firms tend to rely on existing partners and internal resources to cope with collective uncertainty, and that they tend to broaden their ties with new friends as they attempt to cope with firm-specific uncertainty. This suggests that responsiveness in new environments calls for new partners. The study in effect underlines the salience of exploration facilitated by a hot spot location during response uncertainty more than during "collective" state uncertainty. Thus:

H2(a): A geographic hot spot location will have a positive impact on a firm's financial market performance both in times of state uncertainty and response uncertainty.

H2(b): The positive effect of a geographic hot spot location on a firm's financial market performance will be greater in times of response uncertainty than in times of state uncertainty. 


\section{Method}

\section{Sample}

We examined the effects of technological and social exploration on firm financial market performance in the context of the information technology sector in the United States. Our data sources included the Compustat North America annual database compiled by Standard \& Poor's, company websites and press articles, and other documents obtained using search criteria related to each firm. We focused on firms operating in the Computer Programming, Data Processing and Other Computer Related Services industry group (SIC codes 7370-7379) and the Computers and Computer Storage Devices group (SIC codes 3571, 3572 and 3575) in the time periods 1995-1998 and 20012004. Our decision to focus on this research setting was motivated by three factors. First, we needed to situate our study in context where technology- and knowledge-based exploration activities could be expected to impact firm financial market performance. Second, there is consensus that this context is characterized by the presence of geographical clusters or hot spots (McCann \& Folta, 2008). Finally, this setting was characterized by significant turbulence over the sample period (see Figure 1).

Our original sample comprised 20,790 firm-years in the period 1995-2004. We removed foreign-incorporated firms trading as American Depository Receipts and all observations where three or more of our variables (e.g., assets, sales, operating income, and shares outstanding) were missing or equal to zero, as we considered this indicative of a firm being inactive. We also removed observations with less than 10 million dollars in revenues, which often belong to peripheral firms in the IT sector, leaving us with 6,279 observations. Next, we excluded 1,499 observations for the period 1999-2000, which constitutes the height of the dotcom bubble. Thus, our final sample comprises 4,780 firm-years.

\section{Dependent Variables}

Drawing on prior literature, we used two measures of firm financial market performance: Tobin's q and market capitalization. This choice was motivated by the fact that emerging technology firms do not generally have a history of revenues or earnings (Trueman, Wong, \& Zhang, 2000), which are among the main determinants of conventional accounting-based measures like return on assets or return on sales.

Tobin's $q$, calculated as the ratio of the market value of the assets of a firm and the book value of its assets, is frequently used as an assessment of the financial performance of firms (e.g., Danzon, Epstein, \& Nicholson, 2007; Higgins \& Rodriguez, 2006). Tobin's q has the benefit of being both generally correlated with traditional measures of accounting performance, such as return on assets and return on sales, and also of capturing firms' future financial performance (Roberts, 1999). The other measure, market capitalization, is calculated for each firm in any given year as the number of shares outstanding multiplied by the share price at the end of the last day of trading. Market capitalization is a particularly valuable measure of the financial performance of technology-intensive firms as it reflects investors'

Figure 1. NASDAQ Composite Index: 1995-2004

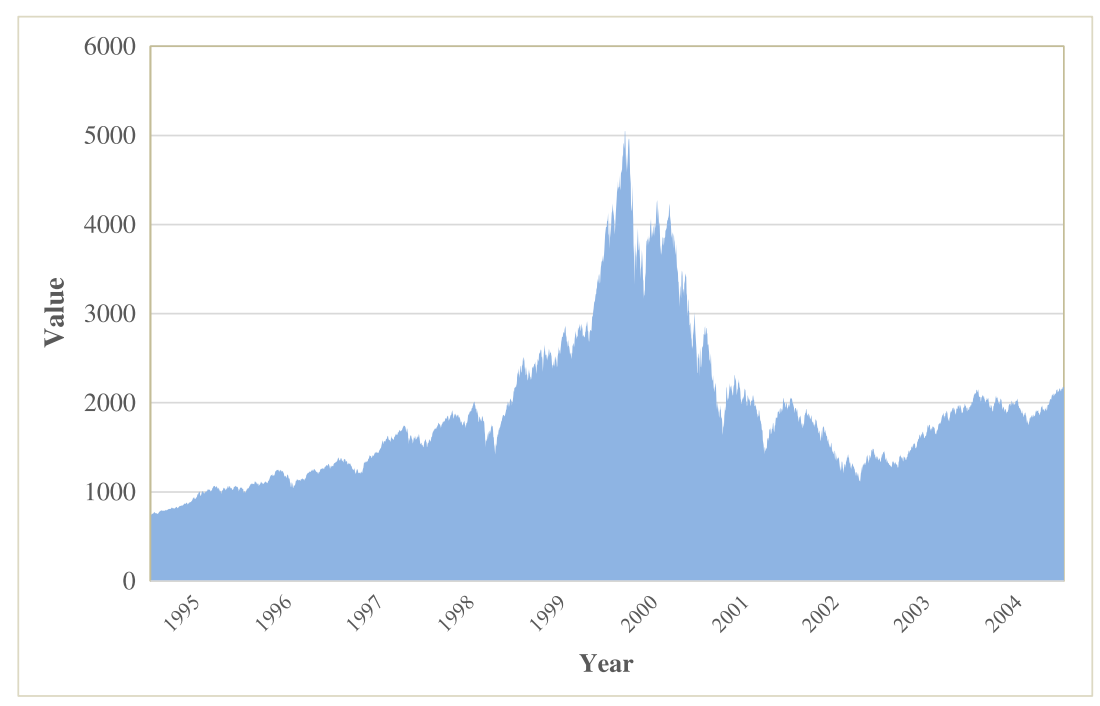


assessment of the value of their future cash flows even though they currently might not be generating any. For example, DeCarolis and Deeds' (1999) study of biotechnology firms used market capitalization to measure firm performance. The authors explained how the "fact that they are years away from any significant revenue stream, have very few tangible assets, are sustaining significant accounting losses, and require large amounts of capital," make market capitalization a valid measure of the performance of these firms (pp. 959-960). In our analysis, we used a logarithmic transformation to control for the skewness of the distribution of this variable.

And finally, we examined how our findings change when we employed an accounting-based measure of performance, namely a firm's Return on Sales, calculated for each fiscal year as operating earnings divided by total sales. Return on sales is frequently used as a measure of profitability in dynamic contexts (e.g., Durand, Bruyaka, \& Mangematin, 2008; McNamara, Peck, \& Sasson, 2013). We had expected the relationship between $R \& D$ intensity and return on sales to be negative, as $R \& D$ is a current expense that tends to suppress current profitability. Instead, in the longer term, as a firm matures, the innovations generated by $R \& D$ ought to result in increased profitability. The latter effect, which was not readily captured by return on sales, was instead captured by both Market Capitalization and Tobin's $q$.

\section{Operationalizing State and Response Uncertainty}

Informed by reports from the popular press, we isolated three periods-predotcom bubble, dotcom bubble, and postdotcom bubble-to operationalize the three specific types of uncertainty. There is general consensus amongst financial analysts that 1999-2000 was the dotcom bubble period. The market sentiment was highly erratic and the period saw the bubble peaking and bursting (see Dai, Shackelford, \& Zhang, 2008). As stated earlier, for the purposes of this study, we focused on the periods immediately preceding and following the dotcom bubble period. For reasons explained below, we took the predotcom bubble period (1995-1998) to be a period of state uncertainty, and the postdotcom period (2001-2004) to be a period of response uncertainty.

State uncertainty (1995-98). This period was characterized by widespread apprehension about whether the sector would be successful. There was tremendous excitement about technological developments, but no one seemed to know what exactly was afoot. This uncertainty is supported by a passage from History of the Internet (Peter, 2003) about the period 1994-99:

For the next five years we were to be bombarded with sometimes realistic and often unrealistic visions of the future; we heard of information superhighways, internet refrigerators and cars, knowledge economies, internet time and internet years, which were vastly different to any time known before, and the dotcom frenzy. Not since the South Sea Island bubble in the 1700s had western economies experienced anything like the dotcom economic bubble. Suddenly everyone wanted a piece of the action; normally astute investors went crazy, and mums and dads added to the frenzy. For some, the dotcom era saw an amassing of great wealth. But almost overnight it disappeared during 2000 and 2001. (para. 12, 13)

Response Uncertainty (2001-04). During this period, it became clear that the investor climate had irreversibly deteriorated, but there was little clarity on the decisions that needed to be made. Firms in the IT sector needed to decide on their reaction to a high-impact event-namely, the dotcom bubble burst that had panicked the stock markets. Inaction was not an option in an environment that was witnessing consolidation, with the surviving players actively scouting externally for promising technologies. By this time, the implications of convergence of technologies, such as computing, Wi-Fi, fibre optics, and communication networks, had become clearer. Firms could visualize the possibilities, but did not know when and how to respond (see Friedman, 2006). The uncertainty faced by IT firms was compounded by the drastic change in regulatory regime, which took place in 2002 with the passage of the SarbanesOxley Act.

\section{Independent Variables}

We measured technological exploration as R\&D intensity, calculated as firms' annual R\&D expenses divided by sales (R\&D/Sales). Measuring $\mathrm{R} \& \mathrm{D}$ intensity in this standard manner allows us to control for the fact that firms producing larger revenue streams are more likely to be able to invest larger amounts in R\&D than firms producing smaller revenue streams. Prior studies observe how deleting observations with missing R\&D expenses is undesirable as it skews the sample towards R\&D-intensive firms, so these observations are set equal to zero (Ciftci \& Cready, 2011).

We measured the intensity of a firm's social exploration with a binary variable equal to 1 if a firm is located in either of the following states: California, Texas, Massachusetts, or New York, or in the cities of Atlanta, Boston, New York, Seattle, or Washington, and 0 otherwise (Hot spot location). These areas were chosen as they have emerged as geographic hubs of information technology innovation within the US (e.g., Pouder \& St. John, 1996). This variable captures the effect on firm profitability of the knowledge spillovers occurring through the social interactions taking place among technology-intensive firms located in these areas.

\section{Control Variables}

We also included in our analysis several variables that could potentially affect a firm's profitability. Size, measured with the natural logarithm of total assets, is included among 
the controls, as is standard in the literature. Controlling for the effect of size is all the more crucial when profitability is measured using financial market measures (DeCarolis \& Deeds, 1999) such as in this case. Additionally, we also included a measure of a firm's age, expressed as the natural logarithm of the number of years from the start of operations (Age) to control for the fact that technology firms tend to become more inertial as they mature (Van de Ven, Polley, Garud, \& Venkataraman, 1999), which in turn could negatively affect their profitability. Also, while technological and social exploration are the conceptual focus of this paper, we recognize that from a resource-based perspective it is possible for other resources and capabilities to be associated with firm performance. Hence, we controlled for two key sources of resource heterogeneity amongst firms. The first source is the yearly values of a firm's stock of intangible assets, such as technological know-how, patents, brands, and goodwill, expressed as a percentage of total assets (Intangibles/Assets). The second source is the yearly values of a firm's property, plant, and equipment as a percentage of total assets (PPE/Assets).

\section{The Model}

We used panel regressions to examine the relation between environmental uncertainty, exploration type, and firm performance. In the following model, the subscript $i$ identifies each single company in our sample and subscript $t$ identifies the year:

$$
\begin{aligned}
& \text { Performance }_{i t}= \beta_{0}+\beta_{1} *\left(R \& D / \text { Sales }_{i t}\right. \\
&+\beta_{2} * \text { Hot spot location } \\
& i t \\
&+\beta_{3} *(\text { Intangible assets } / \text { Assets })_{i t}+ \\
&+\beta_{4} *(\text { PPE } / \text { Assets })_{i t}+\beta_{5} * \text { Size }_{i t} \\
&+\beta_{6} * \text { Age }_{i t}+\beta_{7} * \text { Performance }_{i t-1}+e_{i t}
\end{aligned}
$$

We estimated three different specifications of this model where firm performance is measured with Tobin's q, market capitalization, and return on sales, respectively. The independent and control variables are those defined above. We also included a measure of firm performance in the prior year $(t-1)$ to avoid specification error in the models (Miller \& Shamsie, 1996). In order to mitigate the influence of outliers, we Winsorized both tails of our dependent variables at the $1^{\text {st }}$ and $99^{\text {th }}$ percentile. Our conclusions do not change with or without Winsorization.

\section{Results}

In order to confirm our theoretical speculation regarding different kinds of uncertainty affecting the predotcom bubble (1995-1998) and postdotcom bubble period (2001-2004), we examined the year-to-year stability in our measures of financial market performance. We conducted our investigation by calculating the correlation coefficients between each of our measures of firm performance in year $t$ and $t-1$, which are reported in Table 1. In the first period, the inter-year correlation for Tobin's q, market capitalization, and return on sales were equal to $47.2 \%, 73.2 \%$, and $37.4 \%$. In the second period, they were $45.0 \%, 79.6 \%$, and $58.6 \%$, respectively. Two out of three measures point to the second period being more stable than the first. This evidence suggests that the period 1995-1998 was characterized by greater uncertainty and unpredictability regarding the future prospects of the industry, a condition that fits the description of state uncertainty as per Milliken (1987). While the period 20012004 was less unpredictable, it showed itself to be an uncertain period in the sense that managers of technology-intensive firms struggled to understand and evaluate the range of strategic responses available to deal with the dotcom bubble burst. Thus, we argue that 2001-2004 fits the description of response uncertainty.

\section{Financial Market Performance and Exploration Activities in Different Uncertainty Periods}

Table 2 compares the performance and exploration activities for the predotcom bubble/state uncertainty period and the postdotcom bubble/response uncertainty period. Firms exhibited generally lower Tobin's q and return on sales in the second period than in the first. For example, the median Tobin's q declined from 1.618 to 1.431 in the postbubble period, while the median return on sales declined from $8.644 \%$ to $3.565 \%$. Conversely, when we measured financial performance as market capitalization, the median firm in the IT sector was more valuable in the postdotcom bubble period than in the predotcom period (4.909 vs. 4.409). We believe that a key background phenomenon underpinning these changes was a wave of consolidations taking place in the aftermath of the dotcom bubble burst. Indeed, in the prior period our sample included 878 firms, while in the latter period it only included 745 firms. This concentration activity is likely to have occurred as the hostile environment posed greater challenges to firm survival, causing weaker firms to go out of business or be acquired by stronger ones. Median R\&D expenses increased from $10.4 \%$ of total sales to $13.7 \%$ of total sales over the period 2001-2004. More observations in our sample are from firms located in a hotspot in the postdotcom period than in the predotcom period (37.8\% vs. $32.3 \%$ ). Thus, we can see that there were considerable changes in both forms of exploration over the period of the study.

Among our firm characteristics variables, firm size and age increased significantly between the two periods. The median size increased from 3.865 to 4.581 , while the median age increased from 2.485 to 2.708 . These findings are consistent with the view that the dotcom bubble burst hastened 


\section{Table 1}

Inter-Year Correlations between Firm Performance Measures by Uncertainty Type

Tobin's q Lag Tobin's q Market capitalization Lag market capitalization Return on sales Lag return on sales

\section{State uncertainty: 1995-1998}

Tobin's q $\quad 1.00$

Lag Tobin's q $\quad 0.472 * * *$

Market capitalization $\quad 0.590 * * *$

Lag market capitalization

Return on sales

Lag return on sales
1.00

$0.457 * * *$

$0.649 * * *$

$0.157 * * *$

$0.389 * * *$
1.00

$0.732 * * * \quad 1.00$

$\begin{array}{lll}0.269 * * * & 0.225 * * * & 1.00\end{array}$

$\begin{array}{lll}0.532 * * * & 0.575 * * * & 0.374 * * *\end{array}$
1.00
1.00

$0.796 * * * \quad 1.00$

$\begin{array}{lll}0.240 * * * & 0.293 * * * & 1.00\end{array}$

$0.374 * * * \quad 0.560 * * * \quad 0.586 * * *$
1.00

Response uncertainty: 2001-2004

Tobin's q

Market capitalization

Lag market capitalization

Return on sales

1.00

$0.450 * * * \quad 1.00$

$0.409 * * * \quad 0.370 * * *$

$0.534 * * *$

$0.173 * * * \quad 0.214 * * *$

$0.349 * * *$

Note: $* * *$ indicates significance at $1 \%$, ** indicates significance at $5 \%$, and $*$ indicates significance at $10 \%$.

a consolidation of the industry, ushering a more competitive environment with fewer players who were older and larger in size. Similarly, intangible assets as a fraction of total assets rose from a median of $0 \%$ in the period 1995-1998 to $10.1 \%$ in the period 2001-2004. Finally, we were unable to find a pattern in the value of property plant and equipment as a percentage of total assets in the two periods.

\section{Effect of Technological Exploration and Social Exploration on Firm Performance}

Table 3 reports the correlation coefficients for our measures in the periods 1995-1998 and 2001-2004. In the state uncertainty period the correlation coefficient between Tobin's q and R\&D intensity was positive and significant $(0.091, \mathrm{p}<0.01)$, and that between $R \& D$ intensity and market capitalization was not significant. The correlation coefficients in the response uncertainty period were negative and significant for Tobin's q $(-0.044, \mathrm{p}<0.05)$ and positive but not significant for market capitalization. Taken together, this evidence suggests that technological exploration tends to be advantageous for firms in times of state uncertainty and to be neutral or at worst counterproductive in periods of response uncertainty, thereby providing preliminary support for $H 1$. As expected, return on sales exhibited a negative correlation with $R \& D$ intensity in both periods $(-0.352$ and $-0.522, \mathrm{p}<0.01)$. The finding that the negative correlation coefficient between R\&D intensity and return on sales for the second period was stronger than it was for the first period also provides some initial support for $H 1$.
Table 3 also shows that hot spot location was positively related to Tobin's q and market capitalization in both state uncertainty and response uncertainty. The correlation coefficients are 0.059 and 0.055 (both $\mathrm{p}<0.01$ ) for Tobin's $\mathrm{q}$ and 0.047 and $0.075(\mathrm{p}<0.05$ and $\mathrm{p}<0.01)$ for market capitalization. Not only was the correlation coefficient positive and significant in both periods, it was comparable or higher in the period after the dotcom bubble. This evidence provides some preliminary support for $\mathrm{H} 2$ (a) and $H 2(b)$. When we used return on sales for a robustness check, we noticed that the correlation coefficient between this measure and hot spot location was negative in state uncertainty and not significant in response uncertainty. A possible reason behind this finding is that firms located in hot spots were relatively young and innovative and invested more in R\&D than did firms located everywhere else in the US, which negatively impacted their income. Indeed, our analysis confirms that firms in hot spots tend to be younger in both periods and have higher R\&D intensity.

Our univariate analysis provides some initial support for $H 1, H 2(a)$ and $H 2(b)$. We now examine the effects of technological and social exploration on firm performance in times of state and response uncertainty in a multivariate setting. The results of our panel regressions are presented in Table 4. The dependent variable is Tobin's q in models (1) - (3), market capitalization in models (4) - (6), and return on sales in models (6) - (9).

From models (1) and (2) of Table 4 we see that when firm performance was measured using Tobin's q, the effect of technological exploration was positive in the period 1995-1998 $(\mathrm{p}<0.10)$ and negative and significant in the period 2001$2004(\mathrm{p}<0.01)$. Social exploration as measured with firms' 
Table 2

Financial Market Performance, Exploration Type, and Firm Characteristics by Uncertainty Type

\begin{tabular}{|c|c|c|c|}
\hline & \multicolumn{2}{|c|}{ Uncertainty type } & \multirow[b]{2}{*}{$\begin{array}{l}\text { t-test/z-test } \\
\text { Pre-Post }\end{array}$} \\
\hline & $\begin{array}{c}\text { State: } 1995-1998 \\
\qquad N=2,502\end{array}$ & $\begin{array}{l}\text { Response: } 2001-2004 \\
\qquad N=2,278\end{array}$ & \\
\hline \multicolumn{4}{|c|}{ Performance: } \\
\hline \multicolumn{4}{|c|}{ Tobin's q } \\
\hline Mean & 2.441 & 1.865 & $9.57 * * *$ \\
\hline Median & 1.618 & 1.431 & $4.89 * * *$ \\
\hline \multicolumn{4}{|c|}{ Market capitalization } \\
\hline Mean & 4.189 & 4.738 & $-8.16^{* * *}$ \\
\hline Median & 4.409 & 4.909 & $-7.72 * * *$ \\
\hline \multicolumn{4}{|c|}{ Return on sales } \\
\hline Mean & 1.820 & -7.123 & $9.17 * * *$ \\
\hline Median & 8.644 & 3.565 & $10.47 * * *$ \\
\hline \multicolumn{4}{|c|}{ Type of exploration: } \\
\hline \multicolumn{4}{|c|}{ Technological: R\&D/Sales } \\
\hline Mean & 0.141 & 0.167 & $-4.07 * * *$ \\
\hline Median & 0.104 & 0.137 & $-6.07 * * *$ \\
\hline \multicolumn{4}{|c|}{ Social: Hot spot location } \\
\hline Mean & 0.323 & 0.378 & $-3.98 * * *$ \\
\hline Median & 0.000 & 0.000 & $-3.98 * * *$ \\
\hline \multicolumn{4}{|c|}{ Firm characteristics } \\
\hline \multicolumn{4}{|c|}{ Size } \\
\hline Mean & 4.127 & 4.753 & $-12.95 * * *$ \\
\hline Median & 3.865 & 4.581 & $-13.68 * * *$ \\
\hline \multicolumn{4}{|l|}{ Age } \\
\hline Mean & 2.409 & 2.610 & $-9.87 * * *$ \\
\hline Median & 2.485 & 2.708 & $-8.93 * * *$ \\
\hline \multicolumn{4}{|c|}{ Intangible assets/Assets } \\
\hline Mean & 0.053 & 0.168 & $-25.52 * * *$ \\
\hline Median & 0.000 & 0.101 & $-28.60 * * *$ \\
\hline \multicolumn{4}{|l|}{ PPE/Assets } \\
\hline Mean & 0.278 & 0.299 & $-2.81 * * *$ \\
\hline Median & 0.219 & 0.223 & -1.01 \\
\hline
\end{tabular}

Note: $* * * * *$, and $*$ indicate significance at $1 \%, 5 \%$ and $10 \%$ respectively.

location in a hot spot was not significantly associated with firm performance in the prebubble period. However, it was instead positively associated with performance in the postbubble period $(\mathrm{p}<0.05)$. These findings are partially consistent with $H 2$ (b). Model (3) provides a more stringent test of our hypotheses as it tests for the moderating effect of the type of uncertainty on the relation between $R \& D$ intensity and hot spot location on Tobin's q. In the model, $R \& D /$ Sales was positive, indicating that technological exploration is associated with a higher Tobin's q in state uncertainty. The coefficient on $R \& D /$ Sales $\mathrm{x}$ Response was negative, consistent with a negative effect of technological exploration on Tobin's q in response uncertainty. The effect of Hot spot location was positive. This result is consistent with a positive effect of social exploration in state uncertainty. The coefficient on Hot spot location $\mathrm{x}$ Response is not significant. Thus Model 3 supports $H 1$ and $H 2$ (a) but not $H 2(b)$. Based on our correlation analysis, we speculate that the negative sign on Hot spot location x Response in Model 3 could be due to the fact that the correlation between Tobin's $q$ and Hot spot location is positive but small while that between Tobin's $q$ and Response is negative and sizeable.

In models (4) - (6) our dependent variable is financial market performance as measured by market capitalization. $R \& D$ intensity has a positive impact on prebubble market capitalization $(\mathrm{p}<0.01)$. This effect, however, becomes negative in the postbubble period, similar to the case of models (1) and (2). In contrast, the coefficient on hot spot location was not significant in the prebubble period but it became positive in the postbubble period. This evidence lends support to $H 1$ and partial support to $H 2(b)$. In model (6), R\&D/Sales was once again positive, consistent with a positive effect of technological exploration in state uncertainty. The interaction term $R \& D /$ Sales x Response was instead negative, a finding suggestive of a negative effect of $\mathrm{R} \& \mathrm{D}$ intensity on market capitalization in response uncertainty. Taken together, these results are consistent with $H 1$. Hot spot location and Hot spot location x Response did not have a significant effect on market capitalization. Thus, Model 6 does not support $H 2(a)$ and $H 2(b)$.

Finally, models (7) - (9) show that when we measured firm performance using return on sales, the coefficient on $R \& D$ intensity was negative in both periods, as expected in light of the arguments presented above. The coefficient on hot spot location instead was negative in the first period $(\mathrm{p}<0.10)$ but not significant in the second. We also noticed how the coefficient on R\&D intensity became more negative in the second period while the coefficient on hot spot location became more positive. Thus, we interpreted these findings as being broadly consistent with $H 1$ and $H 2(b)$. In model (9), the coefficient on $R \& D /$ Sales was negative, consistent with a negative effect of technological exploration in state uncertainty. The interaction term $R \& D /$ Sales $\mathrm{x}$ Response was also negative. This finding indicates that $R \& D$ intensity has a more negative effect on market capitalization in response uncertainty, consistent with the prediction of $H 1$. The coefficients on Hot spot location and Hot spot location $\mathrm{x}$ Response were not significant. Thus $H 2(a)$ and $H 2(b)$ are not supported.

\section{Discussion}

\section{Summary}

We offered a theoretical rationale anchored in the knowledge-based view of the firm and the organizational learning literature for the effect of different types of knowledge resources on firm performance in specific types of 


\section{Table 3}

Correlation Coefficients by Uncertainty Type

\begin{tabular}{|c|c|c|c|c|c|c|c|c|c|c|}
\hline & & 1. & 2. & 3. & 4. & 5. & 6. & 7. & 8. & 9. \\
\hline & \multicolumn{10}{|c|}{ State uncertainty: 1995-1998 } \\
\hline 1. & Tobin's Q & 1.00 & & & & & & & & \\
\hline 2. & Market capitalization & $0.590 * * *$ & 1.00 & & & & & & & \\
\hline 3. & Return on sales & $0.140 * * *$ & $0.270 * * *$ & 1.00 & & & & & & \\
\hline 4. & R\&D/Sales & $0.091 * * *$ & 0.022 & $-0.352 * * *$ & 1.00 & & & & & \\
\hline 5. & Hot spot location & $0.059 * * *$ & $0.047 * *$ & $-0.038 *$ & $0.037 *$ & 1.00 & & & & \\
\hline 6. & Size & $0.160 * * *$ & $0.744 * * *$ & $0.247 * * *$ & $-0.060 * * *$ & $0.041 * *$ & 1.00 & & & \\
\hline 7. & Age & $-0.070 * * *$ & $0.205^{* * *}$ & $0.283 * * *$ & $-0.167 * * *$ & $-0.08 * * *$ & $0.255 * * *$ & 1.00 & & \\
\hline 8. & Intangible assets/Assets & $-0.080 * * *$ & -0.012 & -0.006 & $-0.081 * * *$ & $-0.048 * *$ & $0.077 * * *$ & $-0.043 * *$ & 1.00 & \\
\hline \multirow[t]{3}{*}{9.} & PPE/Assets & $-0.143 * * *$ & $-0.097 * * *$ & $-0.043 * *$ & $-0.039 * *$ & -0.031 & -0.025 & $0.173 * * *$ & $-0.094 * * *$ & 1.00 \\
\hline & & 1. & 2. & 3. & 4. & 5. & 7. & 8. & 9. & 10. \\
\hline & \multicolumn{10}{|c|}{ Response uncertainty 2001-2004 } \\
\hline 1. & Tobin's Q & 1.00 & & & & & & & & \\
\hline 2. & Market capitalization & $0.409 * * *$ & 1.00 & & & & & & & \\
\hline 3. & Return on sales & $0.173 * * *$ & $0.240 * * *$ & 1.00 & & & & & & \\
\hline 4. & R\&D/Sales & $-0.044 * *$ & 0.005 & $-0.522 * * *$ & 1.00 & & & & & \\
\hline 5. & Hot spot location & $0.055 * * *$ & $0.075^{* * *}$ & -0.014 & $0.043 * *$ & 1.00 & & & & \\
\hline 6. & Size & $0.039 *$ & $0.806^{* * *}$ & $0.232 * * *$ & -0.011 & $0.058 * * *$ & 1.00 & & & \\
\hline 7. & Age & $-0.043 * *$ & $0.170 * * *$ & $0.313 * * *$ & $-0.203 * * *$ & $-0.139 * * *$ & $0.190 * * *$ & 1.00 & & \\
\hline 8. & Intangible assets/Assets & $-0.094 * * *$ & $0.064 * * *$ & $0.081 * * *$ & $-0.084 * * *$ & $0.070 * * *$ & $0.147 * * *$ & 0.023 & 1.00 & \\
\hline 9 & PPE/Assets & -0.023 & $-0.237 * * *$ & $-0.047 * *$ & $-0.074 * * *$ & $-0.110 * * *$ & $-0.234 * * *$ & 0.034 & $-0.222 * * *$ & 1.00 \\
\hline
\end{tabular}

Note: $* * *, * *$ and $*$ indicate significance at $1 \%, 5 \%$, and $10 \%$ respectively.

uncertainty. We also provided some empirical evidence in support of our arguments. Overall, our results suggest that technological exploration through investment in $\mathrm{R} \& \mathrm{D}$ is positively associated with a firm's financial performance in times of state uncertainty, but not in times of response uncertainty. Further, we found mixed evidence on the effect of social exploration, as facilitated through a hot spot location, on a firm's financial performance during state and response uncertainty.

\section{Contributions to Scholarship}

The RBV has been criticized for ignoring where, when, and how resources become useful (Priem \& Butler, 2001). Our study offered some answers by indicating that the effectiveness of specific exploratory resources may be contingent upon specific types of uncertainty. We also implied that there may be a way to address what has been described in the literature as the causal ambiguity paradox (King \& Zeithaml, 2001). The extant literature cautions that while knowledgebased resources can help firms cope with uncertainty (e.g., Miller \& Shamsie, 1996), the resources, being inherently complex (Barney, 1985), can prove double-edged. So, the resources may render competitive imitation difficult, but by the same token, they can prevent managers of the focal firm from understanding cause-effect relationships. Our results imply that scholars can help overcome the causal ambiguity paradox and enhance the validity of managerial decisions by developing fine-grained taxonomies of not only resource types, but also of resource deployment strategies. We believe that our results provide some support for the intuition that firm-level resource deployment decisions may be better understood by narrowing one's focus.

It is worth noting that conceptually, the need to closely match specific types of knowledge-based resources with specific types of uncertainty to facilitate new learning and positively impact firm performance resonates with Ashby's (1958) law of requisite variety, which posits that a system can survive only if its internal complexity levels match the complexity levels in its external environment. Finally, we believe that our study also introduced an innovative way of measuring constructs that are of interest to scholars. The study demonstrates how one might obviate the need to rely on subjective self-reported managerial responses by using hot spot location and $\mathrm{R} \& \mathrm{D}$ investment as proxy measures for social exploration and technological exploration respectively.

\section{Applied Implications}

Our results imply that when and where possible, firms should establish their operations in a hot spot location. Furthermore, while we have argued that the mere presence at a hot spot would pay dividends during times of response uncertainty, our logic implies that firms that proactively 


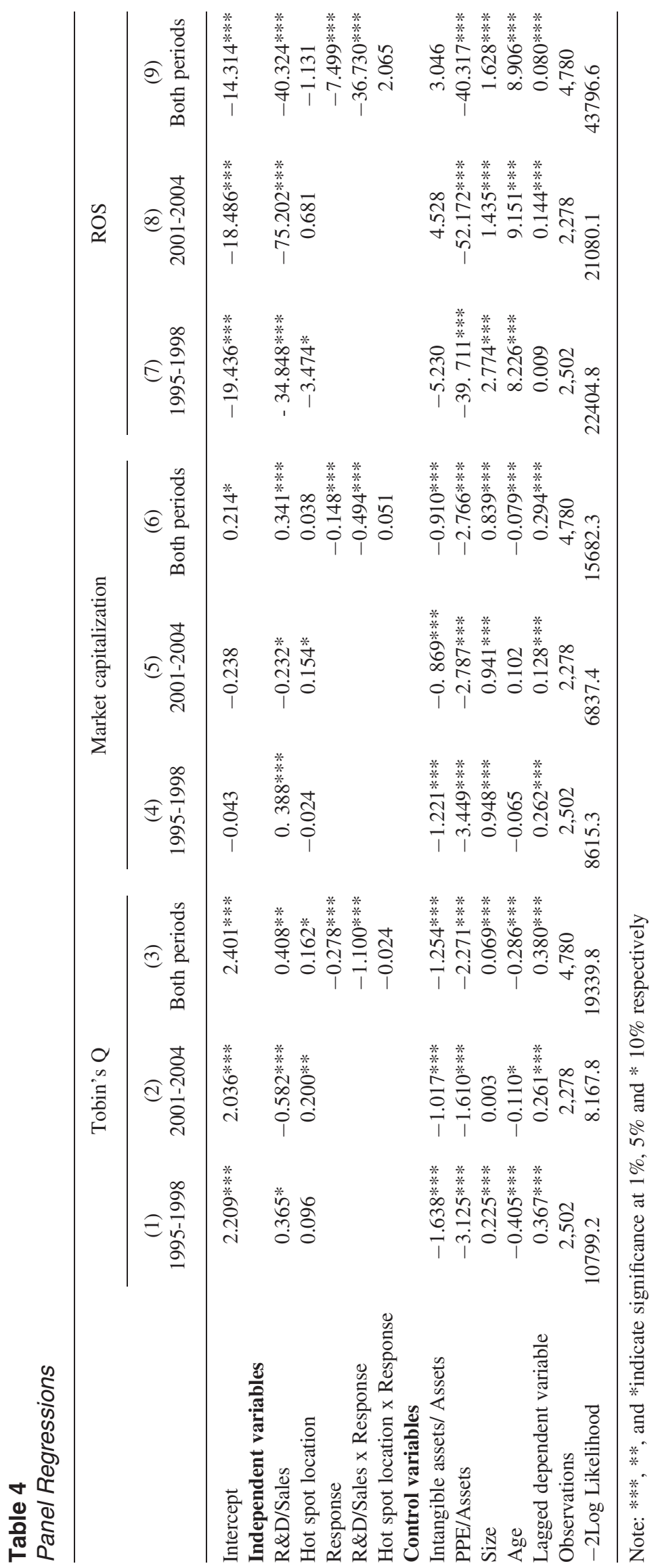


allocate resources to build managerial- and firm-level social networks (through research alliances, hosting industry-level seminars, and so forth) would out-perform the less proactive firms. From a firm's perspective, it bears reiteration that it must simultaneously deploy resources for both exploration and exploitation. Our study highlights that there may be contingencies under which the emphasis on either ought to shift. In effect, we recommend that firms should retain the flexibility to rapidly redeploy their resources as the nature of uncertainty changes. This further suggests the need for retaining some organizational slack at all times.

\section{Limitations and Future Research Directions}

Our study is not without limitations. Firstly, while our study circumvents the need to rely on managers' subjective assessment of environmental uncertainty, it implicitly assumes that in each period managers mainly experience only a certain type of uncertainty. However, it appears reasonable that managers could simultaneously experience several types of uncertainty. Moreover, it does not explicitly consider that managerial perceptions could also get influenced by organizational characteristics. For instance, managers who have greater confidence in their organization's strategic planning processes may not perceive response uncertainty as acutely as their counterparts from other poorly-prepared organizations (Ashill \& Jobber, 2010). Secondly, clusters differ in terms of their geographical signatures (i.e., size, economic diversity, and innovativeness) (e.g., Bell \& Deng, 2013). Scholars should consider teasing apart the characteristics of clusters and study how variations between and within clusters moderate the relationship between the types of uncertainty and firm performance. Our study suggests that it might prove fruitful to develop nomological networks linking technological exploration, hot spot location, and resource structuring in the context of coping with specific types of uncertainty. Thirdly, researchers have conceptualized exploration and exploitation as being part a resource deployment continuum and that, irrespective of where a firm is at a given point in time, it must retain the ability to situate itself in the midpoint (e.g., Gibson \& Birkinshaw, 2004; Lavie et al., 2010). Thus, future studies might find it fruitful to examine how the effect of different types of exploration and exploitation strategies on firm performance varies depending on the type of environmental uncertainty. Fourthly, our arguments need be further developed and tested across different industries and different stages of the industry life cycle. And finally, as we relied on secondary data we were unable to control for potential confounding effects by including other variables that might impact the performance of the IT firms in our sample such as a firm's strategy and human resource orientation. Future studies could augment our findings by using survey instruments to minimize subjectivity in deriving relevant measures when not publicly available.
JEL Classifications: D81, M00, L10

\section{References}

Ashby, W.R. (1958). Requisite variety and its implications for the control of complex systems. Cybernetica, 1(2), 83-99.

Ashill, N., \& Jobber, D. (2010). Measuring state, effect and response uncertainty: Theoretical construct development and empirical validation. Journal of Management, 36(5), 1278-1308.

AT\&T Newsroom (2014). The Chernin Group and AT\&T create new venture to acquire, invest in and launch online video businesses. Retrieved from http://about.att.com/story/the chernin_group_and_att_create_new_venture_to_acquire_invest_in_and_launch_online_video_businesses.html

Barney, J. (1985). Information cost and the governance of economic transactions. In R.D. Nacamalli \& A. Rugiadini (Eds.), Organizations and Markets, (pp. 347-372). Milan: Societa Editrice it Milano.

Barney, J. (1991). Firm resources and sustained competitive advantage. Journal of Management, 17(1), 99-120.

Beckman, C., Haunschild, P., \& Phillips, D. (2004). Friends or strangers? Firm-specific uncertainty, market uncertainty, and network partner selection. Organization Science, 15(3), 259-275.

Bell, G.G., \& Deng, S. (2013). Beyond clusters: How regional geographic signature affects firm value and risk. Canadian Journal of Administrative Sciences, 30(2), 71-85.

Ciftci, M., \& Cready, W.M. (2011). Scale effects of R\&D as reflected in earnings and returns. Journal of Accounting and Economics, 52(1), 62-80.

Combs, J., Ketchen, D., Jr, Ireland, R.D., \& Webb, J.W. (2011). The role of resource flexibility in leveraging strategic resources. Journal of Management Studies, 48(5), 1098-1125.

Crossan, M., \& Apaydin, M. (2010). A multidimensional framework of organizational innovation: A systematic review of the literature. Journal of Management Studies, 47(6): 1154-1191.

Dai, Z., Shackelford, D., \& Zhang, H. (2008). Capital gains taxes and stock return volatility: evidence from the Taxpayer Relief Act of 1997. Dallas mimeo: University of Texas.

Danzon, P., Epstein, A., \& Nicholson, S. (2007). Mergers and acquisitions in the pharmaceutical and biotech industries. Managerial and Decision Economics, 28(4/5), 307-328.

DeCarolis, D.M., \& Deeds, D.L. (1999). The impact of stocks and flows of organizational knowledge on firm performance: an empirical investigation of the biotechnology. Strategic Management Journal, 20(10), 953-968.

Durand, R., Bruyaka, O., \& Mangematin, V. (2008). Do science and money go together? The case of the French biotech industry. Strategic Management Journal, 29(12), 1281-1299.

EY News Release (2012). Macroeconmic uncertainty catches up with the technology sector. Retrieved from http://www.ey. com/GL/en/Newsroom/News-releases/Macroeconomic-uncertainty-catches-up-with-technology-sector

Friedman, T.L. (2006). The world is flat [updated and expanded]: A brief history of the twenty-first century. New York, NY: Macmillan.

Gibson, C.B., \& Birkinshaw, J. (2004). The antecedents, consequences, and mediating role of organizational ambidexterity. Academy of Management Journal, 47(2), 209-226.

Grant, R.M. (1996). Toward a knowledge-based theory of the firm. Strategic Management Journal, 17(winter special issue), 109-122. 
Gubbins, C., \& Dooley, L. (2014). Exploring social network dynamics driving knowledge management for innovation. Journal of Management Inquiry, 23(2), 162-185.

Gupta, A.K., Smith, K.G., \& Shalley, C.E. (2006). The interplay between exploration and exploitation. Academy of Management Journal, 49(4), 693-706.

Helfat, C.E., Finkelstein, S., Mitchell, W., Peteraf, M.A., Singh, H., Teece, D.J., \& Winter, S.G. (2007). Dynamic capabilities: Understanding strategic chance in organizations. Oxford, U.K.: Blackwell Publishing.

Henderson, A.D. (1999). Firm strategy and age dependence: A contingent view of the liabilities of newness, adolescence, and obsolescence. Administrative Science Quarterly, 44(2), 281-314.

Higgins, M., \& Rodriguez, D. (2006). The outsourcing of R\&D though acquisitions in the pharmaceutical industry. Journal of Financial Economics, 80(2), 351-383.

Jakopin, N.M., \& Klein, A. (2012). First-mover and incumbency advantages in mobile telecommunications. Journal of Business Research, 65(3), 362-370.

Jansen, J.J., Van Den Bosch, F.A., \& Volberda, H.W. (2006). Exploratory innovation, exploitative innovation, and performance: Effects of organizational antecedents and environmental moderators. Management Science, 52(11), 1661-1674.

King, A.W., \& Zeithaml, C.P. (2001). Competencies and firm performance: examining the causal ambiguity paradox. Strategic Management Journal, 22(1), 75-99.

Kogut, B., \& Zander, U. (1996). What firms do? Coordination, identity and learning. Organization Science, 7(5), 502-518.

Kogut, B., \& Zander, U. (1992). Knowledge of the firm, combinative capabilities and the replication of technology. Organization Science, 3(3), 383-397.

Kukalis, S. (2010). Agglomeration economies and firm performance: The case of industry clusters. Journal of Management, 36(2), 453-481.

Lavie, D., Stettner, U., \& Tushman, M.L. (2010). Exploration and exploitation within and across organizations. The Academy of Management Annals, 4(1), 109-155.

Leonard-Barton, D. (1992). Core capabilities and core rigidities: A paradox in managing new product development. Strategic Management Journal, 13(S1), 111-125.

Levinthal, D.A., \& March, J.G. (1993). The myopia of learning. Strategic Management Journal, 14(winter special issue), 95-112.

Li, C.R. (2013). Disentangling the effect of exploratory learning and exploitative learning in product innovation process. Canadian Journal of Administrative Sciences, 30(2), 101-114.

Li, Y., Chen, H., Liu, Y., \& Peng, M.W. (2014). Managerial ties, organizational learning, and opportunity capture: A social capital perspective. Asia Pacific Journal of Management, 31(1), 271-291.

Makadok, R. (2001). Toward a synthesis of the resource-based and dynamic-capability views of rent creation. Strategic Management Journal, 22(5), 387-401.

March, J. (1991). Exploration and exploitation in organizational learning. Organization Science, 2(1), 71-87.

Marshall, A. (1920). Principles of Economics. London, UK: MacMillan.

Matusik, S.F., \& Fitza, M.A. (2012). Diversification in the venture capital industry: leveraging knowledge under uncertainty. Strategic Management Journal, 33(4), 407-426.

McCann, B., \& Folta, T. (2008). Location matters: Where have been and where might we go in agglomeration research. Journal of Management, 34(3), 532-565.
McCann, B., \& Folta, T. (2009). Demand- and supply-side agglomerations: Distinguishing between fundamentally different manifestations of geographic concentration. Journal of Management Studies, 46(3), 362-392.

McKelvie, A., Haynie, J.M., \& Gustavsson, V. (2011). Unpacking the uncertainty construct: Implications for entrepreneurial action. Journal of Business Venturing, 26(3), 273-292.

McNamara, P., Peck, S.I., \& Sasson, A. (2013). Competing business models, value creation and appropriation in English football. Long Range Planning, 46(6), 475-487.

Miller, D., \& Shamsie, J. (1999). Strategic responses to three kinds of uncertainty: Product line simplicity at the Hollywood film studios, Journal of Management, 25(1), 97-116.

Miller, D., \& Shamsie, J. (1996). The resource-based view of the firm in two environments: the Hollywood film studios from 1936 to 1965. Academy of Management Journal, 39(3), 519-543.

Milliken, F.J. (1987). Three types of perceived uncertainty about the environment: State, effect and response uncertainty. Academy of Management Review, 12(1), 133-143.

Mitchell, R.J., Shepherd, D.A., \& Sharfman, M.P. (2011). Erratic strategic decisions: when and why managers are inconsistent in strategic decision making. Strategic Management Journal, 32(7), 683-704.

O'Reilly, C., \& Tushman, M. (2013). Organizational ambidexterity: Past, present and future. The Academy of Management Perspectives, 27(4), 313-323.

Peter, I. (2003). The history of the internet -- the dotcom bubble. Retrieved from www.nethistory.info/

Pouder, R., \& St. John, C. (1996). Hot spots and blind spots: Geographic clusters of firms and innovation. Academy of Management Review, 21(4), 1192-1225.

Priem, R.L., \& Butler, J.E. (2001). Is the resource-based "view" a useful perspective for strategic management research? Academy of Management Review, 26(1), 22-40.

Roberts, P. (1999). Product innovation, product-market competition and persistent profitability in the U.S. pharmaceutical industry. Strategic Management Journal, 20(7), 655-670.

Sidhu, J., Volberda, H., \& Commandeur, H.R. (2004). Exploring exploration orientation and its determinants: Some empirical evidence. Journal of Management Studies, 41(6), 913-932.

Sosa, L.M. (2013). Decoupling market incumbency from organizational prehistory: Locating the real sources of competitive advantage in R\&D for radical innovation. Strategic Management Journal, 34(2), 245-255.

Stuart, T. (2000). Interorganizational alliances and the performance of firms: a study of growth and innovation rates in a high-technology industry. Strategic Management Journal, 21(8), 791-811.

Trueman, B., Wong, F., \& Zhang, X. (2000). The eyeballs have it: Searching for the value of Internet stocks. Journal of Accounting Research, 38 (supplement), 137-162.

Tushman, M.L., \& O’Reilly, C.A. 1996. Ambidextrous organizations: Managing evolutionary and revolutionary change. California Management Review, 38(4), 8-30.

Urgal, B., Quintas, M., \& Arevalo-Tome, R. (2013). Knowledge resources and innovation performance: the mediation of innovation capability moderated by management commitment. Technology Analysis and Strategic Management, 25(5), 543-565.

Van de Ven, A.H., Polley, D.E., Garud, R., \& Venkataraman, S. (1999). The innovation journey. New York: Oxford University Press. 